\title{
Atlanticism and the Changing Dynamics of European Security in the 'New Global Order'
}

\author{
Michael O'NEILL
}

\begin{abstract}
The Atlantic Alliance was the bedrock of western security throughout the postwar decades. Theend of the Cold war and the subsequent changes this historic outcome has wrought in the international order has brought altogether new challenges to the Atlantic Community, requiring both the American and European partners old and new, to rethink their security and foreign policy priorities. The paper reviews this process of international change and the challenges this has brought to the idea of Atlanticism.
\end{abstract}

Keywords: Atlanticism; Europe; America; security; Cold War; foreign policy

\section{Debating Atlanticism: NATO quo vadis?}

The first NATO Secretary General Hastings Ismay defined the organisation's raison d'être as follows: "To keep the Americans in (Europe) the Russians out and the Germans down". Today, both the USA and the Europeans see NATO's central purpose in broadly similar terms, as insurance against a reviving Russia, and even (though let it not be said too loudly!) as a collective guarantee vis-a-vis a reunified and revived Germany. However this broad strategic objective occurs nowadays within a much-changed security environment. The critical issue now is how the Atlantic community should operate in an altogether different global order from that which brought it into being.

Trying to reconcile the two historic 'halves' of Europe, to re-integrate east and west in the enlargement negotiations for both NATO and the EU has been a far from straightforward process.Following the initial euphoria that mostly greeted the fall of the Berlin wall the ensuing process has been fraught with misconceptions, misplaced expectations, and no less by false hopes and disappointments on all sides. The circumstances of enlargement revealed much about the dynamics of European integration, both its limits and its prospects. The focus of the discussion here is the impact of these historic developments on regional security, the consequences for Atlanticism in the post-Cold War age, and indeed whether a panEuropean security policy within NATO or without is a realistic option.

Three critical issues are suggested by this particular inquiry. In the first instance the significance of enlargement for the security debate in both the EU and the USA, and no less for relations between them. A related question is the impact on policy of this narrative about regional and Western security, and likewise its consequences for Atlantic relations and for the very idea of 'Atlanticism' per se. What is the impact of the EU and NATO enlargements for Western security?And 
in what way should we measure success here, 'successful' for whom: for the USA by extending the reach of its own its security strategy in 'the new world order, for the EU's role in stabilising a potentially turbulent neighbourhood, or indeed successful for both sides because of the positive impact of enlargement on Atlantic relations?

The second principal question is what these enlargements have meant for the new applicants, the post-1989 demandeurs? Whether and how far the process has contributed to the 'successful' domestic stabilisation of the accession states and to their security in what is a problematic neighbourhood? A final consideration for this brief review of options and consequences for regional security is the question of 'futures'. How should we assess the impact of enlargement for regional and western security over the longer term?

\section{The Cold War's strategic aftermath}

The end of the Cold War began a debate about European security that is far from being resolved. On the one side there are bold predictions about the 'end of an era', the prospect of a wholly new security agenda for what used to be called 'the West'. And on the other side the claim that the Atlantic Alliance will, indeed must survive albeit reformed. ${ }^{1}$ In fact, the actual situation is altogether more nuanced, neither an end-game nor easy continuity, but instead a process of mutual adaptation to fastchanging circumstances and to novel security and political challenges. Atlanticism was never an easy relationship; it was problematic for some Western Europeans and Americans alike from the outset. So recent frictions are nothing new and they do not necessarily signify a parting of the ways. Fall-outs between Europe and Washington have arisen periodically over everything from the war in Vietnam, Washington's singular approach to détente, the emplacement of American weaponry on European soil, Washington's response to the 1974 oil crisis, and on to all manner of trade disputes from bananas to agricultural subsidies, and much more.

The end of the Cold War saw significant change in NATO's strategic direction, and not least reinforced American reticence about relations with Europe both 'old' and 'new'. ${ }^{2}$ Washington's immediate concern was security for the former Soviet satellite states, although unsure about how the former Warsaw pact countries could usefully contribute to this objective, and not least what the negative externalities of such an enlargement would have on a Russia struggling to come to terms with its sudden loss of international heft. Even as this delayed NATO enlargement

1 J. Howorth, "France, Britain and the Euro-Atlantic crisis", in Survival 45, no. 4, 2003-4, pp. 173-92.

2 F. Heisbourg, "The Future of the Atlantic alliance: Whither NATO, Whether NATO?", The Washington Quarterly 15, no. 2, 1992, pp. 127-39. 
Washington continued to promote EU enlargement, preferring Brussels to take the lead role in stabilising its own region as America shifted its security priorities away from Europe and embraced a wider global outlook.

Washington's objections here were a mix of ideology and self-interest. On the one hand, to underpin democratic values, commitment to a market economy and furtherance of human rights seen as the surest foundation for securitising the region against latent threat. And on the other hand to use the reforms and the prosperity that would follow from EU membership to thwart residual Russian ambitions in what Moscow still saw as its own geo-political hinterland. Accordingly, Washington saw both enlargements as mutually supportive, as a cultural and a strategic commitment by Western democracies, each one underpinning the other. For the most part the CEECs shared this outlook, seeing NATO as both the most reliable source of political stability for their fragile democracies and their principal security guarantee against residual Russian interests in the region. But even the best laid plans sometimes go awry, and 'events' in Europe obliged Washington to revise its plans with the outbreak of civil war in the Balkans. ${ }^{3}$

In the immediate aftermath of the Cold War the 'West' did embark on a twintrack enlargement, extending membership of both NATO and the EU to those former Communist states that sought membership. Good intentions however were soon confronted by complex realities brought all manner of difficulties such that Washington and the EU15 states alike became concerned about the impact of sudden 'big bang' enlargements. The enlargements stalled, becoming a protracted and for some EU15 member states even a reluctant process.

Events in Bosnia confirmed Washington's security dilemma and underlined its own freedom of action, not least the EU's tardy response there that required Washington to take the lead in using military force to bring Serbia to the negotiating table at Dayton and later over the Kososvo imbroglio. The USA could not easily relinquish its role in European security. But over the longer term Washington remained convinced that the Cold War was indeed a turning point for Atlanticism, for its own security policy, with resources and strategic priorities concentrated more exclusively on homeland security by operating on global level rather than giving primacy to the European theatre. America now looks beyond Europe for the main source of threats and focuses now on preventing the spread of WMDs and nuclear proliferation, and on countering the threat of 'new' terrorism and what are seen as 'failed' states. ${ }^{4}$

The fall-out from the break-up of the Yugoslavian federation also confirmed America's long-held view that Europe must take greater responsibility for its own security. This priority shift was reflected in James Baker's observation that

3 R. Holbrooke, “America: A European Power", in Foreign Affairs 83, no. 4, 1995, pp. 2-7.

4 B. Buzan, People, States and Fears: An Agenda for International Security Studies in the Post-Cold War Era, Harvester Press, Hemel Hemstead, 1991. 
Washington has 'no dog in that (Balkans) fight', a shift confirmed by the Clinton administration's embrace of an 'Asia first policy'. ${ }^{5}$ Washington's immediate priority after 1989 was the stability of the former Communist states now seeking membership of both the EU and NATO. As Washington saw it the enlargement of these formerly Western institutions would ensure regional peace and bring stability through prosperity, a neat conclusion to the Cold War.

\section{Trans-Atlantic relations post-Iraq}

The onset of the war in Iraq war in 2003 only confirmed Washington's determination to realign its security policy away from the Atlantic region, in the process downgrading what for a clear half century had been its principal security commitment. The fall-out with some leading EU states over Iraq justified Washington's reduced commitment to Atlanticism, its preference for a more utilitarian and no less a more unilateral approach to relations with erstwhile allies.

In so far as Atlanticism remains important in Washington, the Alliance is now denominated more in bilateral terms than as collective security, ad hoc relations and 'coalitions of the willing' for whatever actions Washington chooses to define as threats to 'global' security. American disengagement from the Balkans, devolving responsibility for peacekeeping there to the EU, resistance to involvement in NATO peacekeeping in Macedonia and Bosnia were all clear signals of strategic revision. If this does not quite amount to wholesale abdication of concern for regional security, it is now 'concern' at a distance, rather more indirect than 'hands on', and without any abiding sense of obligation underpinned by military involvement.

\section{Burden sharing: a new security balance?}

By the mid-2000s then it was becoming clear that NATO was undergoing significant strategic transformation. Whilst the organisation's security guarantee to the CEECs did remain central to NATO's mission, the European and American sides of the 'partnership' had different if not quite divergent security priorities. The European states are as reticent as they have always been for the most part about undertaking 'out of area' engagements. Whereas the USA is reluctant to contribute to peacekeeping and soft security tasks in the wider European neighbourhood, preferring instead to lead 'coalitions of the willing' in undertaking selective military operations as and when Washington determined. ${ }^{6}$

5 M. Cox, US ForeignPolicy after the Cold War: Superpower without a Mission?, Pinter London, 1995.

6 A. Cottey, "Globalisation or Redundancy?" in Contemporary Security Policy,volume 25, no. 3, 2004, pp.1-30. 
Above all Washington is more exercised now by 'burden sharing', expecting the Europeans to shoulder greater responsibility not only for regional security but also 'out of area'. The outcome is an uneasy compromise for both sides: NATO took over responsibility (2003) for the command and control of international peacekeeping operations in Afghanistan, its first mission outside Europe and subsequently and significantly extended its force levels there, and likewise played the lead role in training Iraq's new security forces. Whereas the so-called 'Berlin-plus' arrangements permit the Europeans to use NATO military assets (military planning / command and control facilities) for operations in which US and other NATO members may choose not to participate, with Washington agreeing to the formation (again in 2003) of a NATO Response Force for regional crisis deployment. $^{7}$

\section{Rethinking Atlanticism: George 'Dubyah's' new security agenda}

This shift in the strategic balance of the Alliance is plain to see from the early 1990s but it was $9 / 11$ that was the real 'game changer', accelerating shifts already underway, altering mindsets on both sides of the Atlantic. ${ }^{8}$ The Bush 'revolution' while hardly a new foreign policy departure certainly raised the stakes, embedding a mindset whereby paranoia as much as strategic logic propelled foreign policy, with its emphasis, indeed obsession, with the so-called 'axis of evil'. The intensification of militarised foreign policy gave priority to a doctrine of preventive war, with firststrike hard power and missile defence against perceived 'threat' as the leitmotif of security policy at the expense of classic diplomacy or active peacekeeping, and in the process widened the breach with Europe. ${ }^{9}$

This breach was emblematically underlined by Donald Rumsfeld's deliberately provocative distinction between 'old' and 'new' Europe, a phrase that signaled both a discernible weakening of the very idea of commonality of interest, and no less of those shared values that had been the ballast of Atlanticism for a generation and more. ${ }^{10}$ What up until then had been gradual American disengagement from, periodic irritation with Europe became a serious fall-out, and one with adverse consequences for Atlanticism. Europe was no longer Washington's principal security commitment as priorities shifted to elsewhere. The Alliance was downgraded, replaced by ad hoc 'coalitions' of those states prepared issue on issue to

7 NATO (2006), Missile Defence at http://www.nato.int/issues/missile_defence/index.html.

8 J. Peterson, “Europe, America, Iraq: Worst Ever, Ever Worsening?", in Journal of Common Market Studies 42, 2004.

9 I. Daalder and J. Lindsay, America Unbound: The Bush Revolution in Foreign Policy, Washington: Brookings Institution, 2003.

10 Rumsfeld, D., Secretary Rumsfeld Speaks on 21 $1^{\text {st }}$ Century Transformation of US Armed Forces, National Defense University, Fort McNair, Washington DC, January $31^{\text {st }} 2002$, at http://www.defense.gov/Speeches/Speech.aspx?SpeechID=183 
unconditionally endorse US policy. Europe meanwhile became increasingly critical of what it saw as confrontational unilateralism, an atmosphere that prompted America's Ambassador to NATO to describe these events as a "near death experience" for that organisation. ${ }^{11}$

\section{How Washington sees European security}

American and European perspectives on the meaning and no less on the value of Atlanticism have undoubtedly eroded trust, weakening consensus about how best to respond to the challenges of the new international order. Critical here is the problem of how to ensure a credible EU security role. For even where there is transatlantic agreement on global security tasks, NATO is now only one of several institutional frameworks available for addressing such challenges and it is not necessarily the first preference for either the EU or America. Europe has as much responsibility for this state of affairs as Washington. NATO will struggle to bridge the growing Atlantic divide unless the Europeans show greater willingness to burden share, to develop a more credible capability than is currently available in the fledgling ESDP with its limited 'battle groups' and less than convincing 'rapid reaction' force capability. Whether the Alliance has a credible future will depend as much on European as on American commitment.

Yet all is by no means lost for Atlanticism, the idea still has some emotional purchase, and no less strategic relevance for Washington. The Atlantic region may not be the keystone of US security policy it once was but it is still seen as an important aspect of Washington's global security strategy. This continuing commitment is a mix of both strategic self-interest and cultural ballast. Current threat perceptions, much as they were during Cold War, are principally about raw politics but not entirely so. From the very beginnings of the Republic foreign policy has been driven as much by values as by interests, and it remains to this day a matter of furthering cherished ideals: democracy, free markets, freedom and so forth, those very principles that one notable commentator who should have known better once foolishly described as now finally assured, the ultimate victory and no less 'the end of history'.

Of course, 'history' as defined in these boastful terms did not end in 1989, and nor will it 'end' any time soon. Washington is now quite aware of that unpalatable truth, realises that it still needs like-minded allies who share these same values, and that very fact indicates a continuing basis for Atlanticism. But things are not quite what they once were even between close allies. The ballast of shared values that underpinned the Alliance from the outset is threatened nowadays by

11 Guardian (London), December $5^{\text {th }} 2003$. 
accelerating cultural and social change, and the idea of partnership continues to experience tensions.

\section{And the Europeans...}

Europe too is facing hard strategic choices as it responds to current security challenges. The shifts in the Atlantic order discussed above have encouraged Europeans, long since ambivalent about over-dependence on Washington, to review the Continent's strategic options. This is less about abandoning Atlanticism altogether and than it is about finding a credible role for Europe within the Atlantic system. ${ }^{12}$ There is still much to play for and though 'Atlanticism' is under strain it is by no means a lost cause. But neither is the Alliance the entrenched community of mutual values and shared interests it once was.

The debate in Europe about security has centred on how far Europe should accommodate Washington's growing unilateralism and the strategic and security policy preferences that follow from this. Whether on the one hand to work principally through NATO, make strategic accommodations with Washington, maximising consensus and cooperation, agreeing a division of labour acceptable to both sides. Or instead, to strike out in a new direction, to develop a more autonomous role for Europe as a counterweight to American power, as France has always preferred to do. ${ }^{13}$ The EU remains divided over this strategic dilemma: Euro-Atlanticists are wary of offending (and indeed alienating) their principal ally, whereas panEuropeanists are more concerned to develop a credible European security policy, more autonomous yet complementary to NATO. ${ }^{14}$

There are those too, often described as Euro-Gaullists, who want Europe to break with Atlanticism, preferring instead a wholly independent security policy. In a riposte to the policy of both recent centre right and centre left governments in France to re-join NATO's integrated command structure, Regis Debray amongst others makes the case for European autonomy as follows: "NATO is useless because it is anachronistic. At a time when every major nation is playing its own hand... when religious pride or cultural identities are being asserted or reinforced, signing up to NATO is not building for the future. What matters now is ad hoc coalitions, bilateral cooperation and practical

12 See the debates in J. Howorth and J. Keeler (eds), Defending Europe: NATO and the Quest for European Autonomy, Basingstoke 2003.

13 H. Grabbe, The EU's Transformative Power: Europeanisation through Conditionality in Central and Eastern Europe, Basingstoke 2006.

14 P. Cornish and G. Edwards, "The Strategic Culture of the EU: A Progress Report", in International Affairs 84, no. 4, 2005, pp. 801-820. 
arrangements, not a simplistically dualistic worldview. NATO is a survivor from a bye-gone age". ${ }^{15}$

\section{The state of Atlanticism: rift or drift?}

Few close observers of the current state of Atlantic relations would deny that these difficult choices are at very core of the rising debate about security options. This is now an altogether looser security community with even the broad ballast of common 'values' that underpinned it from the outset now diminished. Nevertheless NATO remains operational, a viable alliance though changed and changing for sure, no longer the steady-state security blanket against 'clear and present' ideological threat that it was in earlier decades. Nevertheless a residual consensus remains about broad objectives albeit with much less agreement now about operational 'means'. ${ }^{16}$

Re-appraisal and re-evaluation are apparent on both sides but whether present flux is merely temporary or implies an ineluctable rift remains to be seen. America too is actively reviewing how far, or indeed whether Europeans are still 'valued partners'. Much is made there of perceived European 'free-riding', what seems to be habitual reticence to undertake (and pay for) burden sharing, widespread censure of a supposed absence of political will to divert public monies from 'expensive' welfare programmes and other public goods to ensure a fairer Atlantic division of labour. ${ }^{17}$ There is growing impatience amongst American commentators for instance with Europe's reliance on soft power rather than doing more of the 'heavy lifting', notwithstanding recent praise from Secretary of State Hilary Clinton for Europe's contribution here. ${ }^{18}$

\section{Explaining'Atlanticist security logics: some theoretic narratives}

How might we explain these differences in security priorities between formerly close allies? International relations theory offers some insights into the motives of key policy actors, explains how and why particular outcomes occur, though of course competing theoretical narratives yield quite different explanations of outcomes. The realist narrative dominant in the American academy sees the

15 Regis Debray, "Why France should leave NATO, a response to the report by foreign minister Hubert Vedrine endorsing the Sarkozy governments re-embrace of NATO strategy", in Le Monde Diplomatique (English edition) April 2013, pp. 12-13.

16 J. Nye, "The US and Europe: Continental Drift?", in International Studies 76, no. 1, 2000, pp. 51-60.

17 D. Gompert and R. Kugler, "Free-Rider Redux: NATO needs to Project Power (And Europe Can't Help)", in Foreign Affairs 74, no. 1, 1995, pp. 3-12.

18 C. Kupchan, "The Atlantic order in transition: The nature of change in US-Europe relations", in J. Anderson, J. Ikenberry, and T. Risse (eds), The End of the West? Crisis and Change in the Atlantic Order, Ithaca, 2008. 
'rational pursuit' by states of what they define as strategic interests as the main driver of policy motives, the principal reason why states with a capacity for exercising power are more disposed to use it to achieve their policy objectives, and especially 'hard' power. ${ }^{19}$ As Robert Kagan has famously made the case, the difference between American and European strategic cultures, and especially their differential will to use hard power as a first reflex of foreign and security policy is itself a reflection of quite different capacities for exerting international and especially military power. ${ }^{20}$

For Kagan this merely confirms wholly different cultural instincts, antithetical indeed divergent outlooks 'across the pond' on the logics of the 'new world order'. The USA 'sees' the world from the perspective of a global superpower, indeed a hyper-power. Europeans on the other hand tend to 'see' the world from the quite different perspective of what are at best 'middling' powers with only a modest strategic capacity and much-reduced global clout. More conscious of the limits of their residual power, European statesmen prefer to use multilateral agency as the less risky strategic option for maximising influence, indeed they make a positive virtue of it. For realists such as Kagan these quite different strategic mindsets are pulling apart the two sides of the Atlantic Community.

Liberal commentators on the other hand are rather more sanguine about the prospects for Atlanticism. As they see it values shape strategic choices as much as they are shaped by them. In this Weberian view of the modus vivendi for political action shared values and common institutions sustain mutual policy objectives on those things that really matter in the Atlantic Community regardless of differential power. Commonality of values figures too in the modish social constructivist narrative, and in this theoretic outlook both reinforces shared historic memory, underpins shared institutions and cements a common outlook on security even across a widening Atlantic. ${ }^{21}$ There is then continuing transatlantic consensus on the dangers of nuclear proliferation, shared antipathy to terrorism, wariness of failed states and broad agreement too about the security challenges to 'free' states, all of which amounts to some continuing consensus on the real challenges facing 'the West' in the new and highly mutable 'world order'. ${ }^{22}$

The assumption here of a simplistic causal link between 'values' and political action, the very idea that merely by participating in shared international institutions

19 See for instance J. Mearsheimer, "Back to the Future: Instability in Europe After the Cold War”, International Studies 15, no. 1, 1999, pp. 5-56; and K. Waltz, "The Emerging Structure of International Politics”, International Security 18, no. 2, 1993.

20 R. Kagan, "Power and Weakness", Policy Review vol. 113, 2002.

21 H. Sijursen, "On the Identity of NATO", in International Affairs 80, no. 4, 2004, pp. 687703; T. Risse-Kappen, "Identity in a Democratic Security Community: The Case of NATO”, in P. Katzenstein (ed), Promoting National Interest, New York, 1996, pp. 359-99.

22 J. Nye, "Conflicts after the Cold War", in The Washington Quarterly 19, no. 1, 1996, pp. 5-24. 
invariably promotes understanding and common purpose is as crudely deterministic in its own way as the realist narrative it seeks to challenge. Simplistic emphasis on values as the critical independent variable is as questionable as the realist assumption of path-dependent power as the driving force behind foreign policy preferences. What each of these contested theoretic narratives does do however is to suggest some explanations, deepening our understanding of causality over 'merely' contingent description, indeed yields insights that are essential for the primary task of the social and behavioural sciences to explain rather than merely to assume a priori the reasons for collective political action, in this as in any policy domain.

That values may be shared between actors who might otherwise have quite different strategic preferences and interests is too complex an issue to be resolved in this short essay. However, the question of why things happen in politics is an important one and merits deeper consideration in as much as much as Atlanticism has long been premised on the very idea of shared cultural affinities. One might reasonably question whether, or how far 'common values' are indeed sufficient cultural cement for binding a community facing altogether new challenges in a fast-changing world.

Does Atlanticism imply and will its continuity depend on enduring 'common values'? Debate about transatlantic 'commonality' or American 'exceptionalism' has been the stuff of a fascinating cultural anthropology from De Tocqueville and Charles Dickens to the present day. ${ }^{23}$ Do shared values necessarily mean common interests, do they imply shared threat assessment, let alone a commitment to respond to perceived threat in any particular way? Might we not reverse the causal link here and argue just as plausibly that shared values notwithstanding, different perceptions of interests and no less of threat may mean diverse, indeed divergent expectations that over time might alter value preferences, thereby weakening the glue of alliance and even sunder longstanding relations?

More is required then for sustaining alliance, underwriting a common security endeavour than merely reliance on values per se. Shared cultural preferences are certainly a necessary prop for bolstering common political purpose but they are hardly sufficient to cement alliance. Indeed there are many on both sides of this debate who question nowadays whether there is any longer an abiding commonality of values or interests across the Atlantic. Frequent and often bitter disputes are explained away by some commentators as merely 'the narcissism of small differences'. ${ }^{24}$ But others are much less convinced, seeing instead a growing cultural lacuna and even irreconcilable ideological differences across the wide ocean,

23 S. M. Lipset, Continental Divide: The Values and Institutions of the United States and Canada, London, 1990.

24 P. Baldwin, The Narcissism of Minor Differences: How America and Europe are Alike, New York, 2011. 
for instance the cultural impact, the mainstreaming of neo-liberal and no less of neo-conservative ideas on American values, amounting to a culture shift that now extends way beyond the Grand Old Party and even its Tea Party insurgents.

Cultural shifts between Europe and America may well be exaggerated but they do exist and they compound other differences rooted in differential power, and just as significant a differential propensity to use it. The cumulate impact of demographic shifts such as growing Hispanicisation, the geographical shift in America's political axis from the Atlantic seaboard to the new South and the West, resistance to gun law reform, continued use of the death penalty and popular as much as political resistance to socialised medicine and quite different views on the role of the state in economic and public policy, are all trends that confirm an ideological lacuna and maybe even an unbridgeable cultural rift between Europeans and Americans. And the cumulative impact of these different value preferences does impact on the security debate, altering strategic expectations and prompting serious re-evaluation of strategic goals and security priorities on both sides.

\section{Of 'Mars' and 'Venus' and the future of Atlantic relations}

This narrative on the extent of transatlantic similarity and difference has its advocates on both sides, and nowhere more so than in the writings of Robert Kagan. For Kagan quite different geo-strategic positions / power capabilities as between the US and Europe reflect fundamentally different assessments, indeed competing priorities about current and impending security challenges. And though the US and Europe do still share some important interests this writer sees quite distinct strategic cultures, deep differences of outlook on both the source and the use of power. ${ }^{25}$

The USA as Kagan sees it is the world's hyper-power it has global interests and responsibilities that incline it to employ hard power as a first reflex of security policy because it can, with the capacity and no less the will to act unilaterally. In this narrative the America 'Mars' both resents and resists what it sees as the (superficial) ethical constraints prescribed by weaker European states who, 'Venus-like', object to first use of hard power and seek to constrain its use even by close allies in pursuit of supposedly shared strategic objectives. Europe's reticence here is deemed to be less about the role of ethics in foreign policy and more the logical consequence of that Continent's own brutal experience of power politics. Two immensely destructive 'civil' wars both reduced Europe's international status and no less diminished its moral authority, disinclining its states thereafter from using force as the first reflex of politics, preferring instead to pursue multi-lateral and negotiated solutions to international problems.

25 R. Kagan, Paradise and Power: America and Europe in the New World Order, London, 2002. 
The overly simplistic juxtaposition in this account between ethics and realpolitik as the elemental drivers of security and foreign policy has not gone unchallenged. Robert Cooper's spirited rebuttal of Kagan's brutal realism for example attributes European reticence about first-use of hard power, aversion to militarised foreign policy, the Continent's altogether readier embrace of civilian or soft power not merely to the differential emphasis Europeans place on ethics per se. And not even to a vague moral predilection amongst Europeans to cooperate rather than talk up conflict as the first instinct of managing security policy. Instead Cooper sees this more benign strategic culture as a direct consequence not of self-indulgent idealism but rather the outcome of brutal experience. For Europeans the experience of twentieth century wars has not meant abjuring the use of power but instead a concerted endeavour to tame it, to channel it into more positive, even progressive ends. To find instituionalised ways of resolving conflicted interests, an experience of a new approach to old problems that translated into the positive legacy of sixty years of mostly successful community-building, regional cooperation and multilateral integration, and even wholly novel supranational governance. ${ }^{26}$

In truth no singular narrative can satisfactorily explain the marked disparity between the strategic cultures of Europe and America: strategic self-interest does play its part in shaping what are quite different, even divergent outlooks on mutual problems. And whereas a residuum of shared values does constrain unalloyed selfinterest, is a brake on the disintegration of a longstanding international alliance, the likely future of this 'special relationship' in a mutable world, and how far is it still 'special' remains problematical for all concerned. This question is less about how deep the differences are between the two sides of the Atlantic Community and rather more about how they might continue to work together on the things that they do still share in common.

\section{Conclusions: a future for Atlanticism?}

Novel security challenges do sustain an abiding sense of common interests across the Atlantic, though rather less so now in the multipolar post- Cold War world. Of course tensions, even fall-outs are hardly a new experience for transatlantic relations. After all this has always been an ambivalent relationship for both sides. But there is no ineluctable sense yet that the Alliance faces its Rubicon, a final parting of the ways, for even the American hyper-power needs allies, reliable partners and the Europeans fit the bill here rather better than most. ${ }^{27}$ Europeans too for their part are far from convinced that a more independent approach to regional

26 R. Cooper, The Breaking of Nations: Order and Chaos in the Twenty-first Century, London 2007.

27 J. Nye, The Paradox of American Power: Why the World's only Superpower Can 't Go it Alone, Oxford, 2002. 
security means giving up on Atlanticism, though there are clear differences with Washington nowadays over both interests and strategy.

Something remains then of a sense of common endeavor that sustained the Alliance over the duration. Europe may no longer be the exclusive let alone the primary theatre for US security but it remains important for Washington, an outreach or in the language of siege warfare a counterscarp of its forward security. Yet there is a discernible shift in how Washington policy wonks see Atlanticism. The emerging global order has altered perceptions on all sides, both about economic and security interests, and though the European theatre remains important for Washington it is much discounted nowadays in the broader scheme of things.

The Obama Administration may have softened the tone of its security policy, forbearing in the gratuitous use of confrontational language preferred by its Republican predecessor, but the shift in Atlantic relations is nevertheless plain to see. Washington continues to reconfigure its security policy, and Europeans too are reviewing where they stand on many of the critical issues that define the new international order. Clearly the Alliance is not what it once was and is aptly described by one close observer of events as much less the unconditional alliance of old and rather more as a conditional and 'elective partnership', an arrangement where both 'sides' opt in and out of close relations as circumstances and events dictate. ${ }^{28}$

What we do glimpse then 'through the glass darkly' from this brief overview of the shifting state of Atlanticism is altogether more problematic relations than in times past. This is now an Alliance where the once firm cement of shared interest and common values is increasingly challenged by the vagaries of a wholly new, a mutable and far from predictable global order. It is too soon to pronounce the end of Atlanticism but we should expect altogether more change than continuity in the direction of relations here in the years and decades ahead.

\section{Bibliography}

Anderson, J., J. Ikenberry, and T. Risse (eds), (2008), The End of the West? Crisis and Change in the Atlantic Order, Ithaca: Cornell University Press.

Baldwin, P., (2011), The Narcissism of Minor Differences: How America and Europe are Alike, New York: OUP.

Buzan, B., (1991), People, States and Fears: An Agenda for International Security Studies in the Post-Cold War Era, Hemel Hemstead: Harvester Press.

Cooper, R., (2007), The Breaking of Nations: Order and Chaos in the Twenty-first Century, London: Atlantic Books.

Cornish, P. and G. Edwards, (2005), "The Strategic Culture of the EU: A Progress Report", in International Affairs 84, no. 4.

28 J. Steinberg, “An Elective Partnership: Salvaging Transatlantic Relations”, in Survival 45, no. 2, 2002, pp. 113-46. 
Cottey, A., (2004), “Globalisation or Redundancy?” in Contemporary Security Policy, volume 25, no. 3 .

Cox, M., (1995), US Foreign Policy after the Cold War: Superpower without a Mission?, London: Pinter.

Daalder, I., and J. Lindsay, (2003), America Unbound: The Bush Revolution in Foreign Policy, Washington: Brookings Institution.

Rumsfeld, D., (2002), Secretary Rumsfeld Speaks on $21^{\text {st }}$ Century Transformation of US Armed Forces, National Defense University, Fort McNair, Washington DC, January $31^{\text {st }} 2002$, at http://www.defense.gov/Speeches/Speech.aspx?SpeechID=183

Gompert, D., and R. Kugler, Free-Rider Redux (1995), "NATO needs to Project Power (And Europe Can't Help)", in Foreign Affairs 74, no. 1.

Grabbe, H., (2006), The EU's Transformative Power: Europeanisation through Conditionality in Central and Eastern Europe, Basingstoke: Palgrave.

Heisbourg, F., (1992), “The Future of the Atlantic alliance: Whither NATO, Whether NATO?", in The Washington Quarterly 15, no. 2.

Holbrooke, R., (1995), “America: A European Power” in Foreign Affairs 83, no. 4.

Howorth, J., (2003), "France, Britain and the Euro-Atlantic crisis", in Survival 45, 2003-4, no. 4. Mearsheimer, J., (1999), "Back to the Future: Instability in Europe after the Cold War", in International Studies 15, no. 1, pp. 5-56.

Howorth, J., and J. Keeler (eds), (2003), Defending Europe: NATO and the Quest for European Autonomy, Basingstoke: Palgrave.

Kagan, R., (2002), "Power and Weakness" in Policy Review, vol. 113.

Kagan, R., (2002), Paradise and Power: America and Europe in the New World Order, London: Atlantic Books.

Kupchan, C. (1990), "The Atlantic order in transition: The nature of change in US-Europe relations", in Lipset, S.M. (ed.), Continental Divide: The Values and Institutions of the United States and Canada, London: Routledge.

NATO, Missile Defence at http://www.nato.int/issues/missile_defence/index.html

Nye, J., (1996), "Conflicts after the Cold War", in The Washington Quarterly 19, no. 1, pp. 5-24.

Nye, J., (2000) “The US and Europe: Continental Drift?”, in International Studies 76, no. 1, pp. 51-59.

Nye, J., (2002), The Paradox of American Power: Why the World's only Superpower Can't Go it Alone, Oxford: OUP.

Peterson, J., (2004), “Europe, America, Iraq: Worst Ever, Ever Worsening?”, in Journal of Common Market Studies 42.

Risse-Kappen, T., (1996), "Identity in a Democratic Security Community: The Case of NATO", in Katzenstein, P. (ed), Promoting National Interest, New York: Columbia University Press, pp. 359-99.

Sijursen, H., (2004), “On the Identity of NATO”, in International Affairs 80, no. 4, pp. 687-703

Steinberg, J., (2002), “An Elective Partnership: Salvaging Transatlantic Relations”, in Survival 45 , no. 2, pp. 113-46.

Waltz, K., (1993), “The Emerging Structure of International Politics”, in International Security 18 , no. 2 . 